\title{
Experimental Study on Methane Production from Hydrate-Bearing Sandstone by Flue Gas Swapping
}

Mu, Liang; von Solms, Nicolas

Published in:

Energy and Fuels

Link to article, DOI:

10.1021/acs.energyfuels.8b01437

Publication date:

2018

Document Version

Peer reviewed version

Link back to DTU Orbit

Citation $(A P A)$ :

$\mathrm{Mu}, \mathrm{L}$., \& von Solms, N. (2018). Experimental Study on Methane Production from Hydrate-Bearing Sandstone by Flue Gas Swapping. Energy and Fuels, 32(8), 8167-8174. https://doi.org/10.1021/acs.energyfuels.8b01437

\section{General rights}

Copyright and moral rights for the publications made accessible in the public portal are retained by the authors and/or other copyright owners and it is a condition of accessing publications that users recognise and abide by the legal requirements associated with these rights.

- Users may download and print one copy of any publication from the public portal for the purpose of private study or research.

- You may not further distribute the material or use it for any profit-making activity or commercial gain

- You may freely distribute the URL identifying the publication in the public portal 
Final accepted manuscript:

Mu, L., \& von Solms, N. (2018). Experimental Study on Methane Production from Hydrate-Bearing Sandstone by Flue Gas Swapping. Energy and Fuels, 32(8), 8167-8174.

https://doi.org/10.1021/acs.energyfuels.8b01437

\title{
Experimental Study on Methane Production from Hydrate-Bearing Sandstone by Flue Gas Swapping
}

\author{
Liang Mu and Nicolas von Solms* \\ Department of Chemical and Biochemical Engineering, Center for Energy Resource Engineering \\ (CERE), Technical University of Denmark, DK-2800 Kgs. Lyngby, Denmark
}

\begin{abstract}
:
Methane recovery from artificial hydrate-bearing sandstones by simulated flue gas swapping was tested using a core flooding experimental setup. Seven groups of experiments were conducted to investigate the effect of hydrate saturation as well as the initial porosity and permeability of sandstones on methane production and carbon dioxide capture. The results show that the $\mathrm{CH}_{4}$ recovery efficiency and the amount of $\mathrm{CO}_{2}$ captured increase with the increase of hydrate saturation at the same initial porosity and permeability of sandstone. The highest $\mathrm{CH}_{4}$ recovery obtained is $51.6 \%$ and $99.4 \%$ of $\mathrm{CO}_{2}$ in simulated flue gas is sequestered in the hydrate phase after swapping at 9.2 MPa and $277.15 \mathrm{~K}$. Hydrate saturation was $82.5 \%$ and the initial porosity and permeability of sandstone are $25.1 \%$ and $49 \mathrm{mD}$, respectively. With the increase of initial porosity and permeability of sandstone, the $\mathrm{CH}_{4}$ recovery efficiency and the amount of $\mathrm{CO}_{2}$ captured increase when other
\end{abstract}


conditions (the hydrate saturation and reaction time) are similar. For investigating the $\mathrm{CH}_{4}$-flue gas swapping mechanism, a micro-differential scanning calorimetry was used to test the heat changes in the whole reaction. No noticeable endothermic or exothermic phenomenon was detected in the $\mathrm{CH}_{4}$ flue gas swapping, which indicates that $\mathrm{CH}_{4}$ hydrate would form mixed hydrates directly instead of going through a dissociation and reformation process. Based on the observed experimental results, a $\mathrm{CH}_{4}$-flue gas swapping mechanism is proposed and the reaction process is found to be essentially controlled by mass transfer.

\section{Introduction}

Gas hydrates are ice-like crystalline compounds in which guest molecules (such as $\mathrm{CH}_{4}, \mathrm{CO}_{2}, \mathrm{~N}_{2}$ ) are closed in cages formed by hydrogen-bonded water molecules under favorable thermodynamic conditions of low temperature and high pressure. Although the hydrate cage lattice can be combined in various ways, only three main types of structures are found in nature: structure I (sI), structure II (sII), and structure $\mathrm{H}(\mathrm{sH}) .{ }^{1}$ Gas hydrate formation is regarded as a serious problem in the petroleum industry since it can induce plugging in pipeline transportation and cause enormous economic losses; therefore, numerous studies has been conducted to address this issue. ${ }^{2}$ On the other hand, naturally occurring gas hydrates have been perceived as a promising alternative energy source due to their giant storage in offshore sediments and permafrost regions. It has been reported that the amount of $\mathrm{CH}_{4}$ stored in gas hydrates is twice the amount of carbon found in all fossil fuels worldwide. $^{3-5}$

How to safely and efficiently recover $\mathrm{CH}_{4}$ from natural gas hydrates remains a pressing challenge, in recent years, $\mathrm{CH}_{4}-\mathrm{CO}_{2}$ swapping has been seen as a potential approach which has certain advantages over other technologies that derive from conventional oil and gas industry to be used for gas hydrate exploitation, such as thermal stimulation, ${ }^{6-11}$ depressurization, ${ }^{12-17}$ chemical inhibitor 
stimulation. ${ }^{18-19}$ Because this method is a non-destructive way of substituting $\mathrm{CH}_{4}$ molecules in the hydrate cage with $\mathrm{CO}_{2}$ molecules, a geological event can be avoided during production. In addition, the direct use of flue gas (around $20 \mathrm{~mol} \% \mathrm{CO}_{2}$ and $80 \mathrm{~mol} \% \mathrm{~N}_{2}$ ) instead of pure $\mathrm{CO}_{2}$ can significantly enhance $\mathrm{CH}_{4}$ recovery and save extra $\mathrm{CO}_{2}$ separation cost before injection. ${ }^{20}$ For investigating the $\mathrm{CH}_{4}$-flue gas swapping mechanism, researchers have conducted their studies from thermodynamic, ${ }^{21-23}$ microscopic, ${ }^{24-26}$ and kinetic perspectives.${ }^{27-30}$ Lee et al ${ }^{20,31-33}$ did a series of studies on $\mathrm{CH}_{4}$-flue gas swapping, where they found that the maximum $\mathrm{CH}_{4}$ recovery efficiency achieved are $84 \%$ and $90 \%$, respectively, for sI and sII or sH gas hydrate. In addition, the first field test by swapping was conducted on Alaska North Slope in 2012: $\mathrm{CH}_{4}$ was successfully produced several days after injecting flue gas into the hydrate-bearing sandstones. ${ }^{34-36}$ However, it is necessary to further investigate the $\mathrm{CH}_{4}$-flue gas swapping before proceeding with large-scale commercial exploitation using this technology, because the $\mathrm{CH}_{4}$ productivity is affected by many factors such as the hydrate saturation, the mass and heat transfer properties of the hydrate-bearing sediments, as well as the swapping reaction rate.

In previous work, we performed preliminarily investigations to ascertain the swapping behavior of $\mathrm{CH}_{4}$ hydrate-bearing sandstone by injecting pure $\mathrm{CO}_{2}$ and $\left(\mathrm{CO}_{2}+\mathrm{N}_{2}\right)$ binary mixtures with different compositions using a core flooding experimental apparatus. Around $46 \%$ of $\mathrm{CH}_{4}$ was produced from its hydrate phase after swapping with $\left(\mathrm{CO}_{2}+\mathrm{N}_{2}\right)$ for 342 hours, the $\mathrm{CH}_{4}$ recovery efficiency is lower than stoichimetric. ${ }^{37}$ For the hydrate-bearing sandstones, the $\mathrm{CH}_{4}$-flue gas swapping is significantly different from that in bulk phase. The $\mathrm{CH}_{4}-\mathrm{CO}_{2}$ swapping method adopted in our previous study was limited by $\mathrm{CO}_{2}$ concentration where the residual free $\mathrm{CH}_{4}$ (which is used to keep the $\mathrm{CH}_{4}$ hydrate from dissociation) decreased the reaction driving force. In this study, this limitation was addressed by performing experiments where firstly the flue gas is injected continuously into the reactor to purge the free methane at a constant pressure and then pressurize it 
to a certain value to start the swapping reaction at a high driving force. Since the exchange performance is sensitive to the mass transfer properties of hydrate-bearing sandstones, this work mainly focuses on how the porosity and permeability of sandstone affect the $\mathrm{CH}_{4}$ recovery in the $\mathrm{CH}_{4}$-flue gas swapping. The results can provide basic research information for natural gas hydrates exploitation by flue gas swapping.

\section{Experimental Section}

\subsection{Apparatus.}

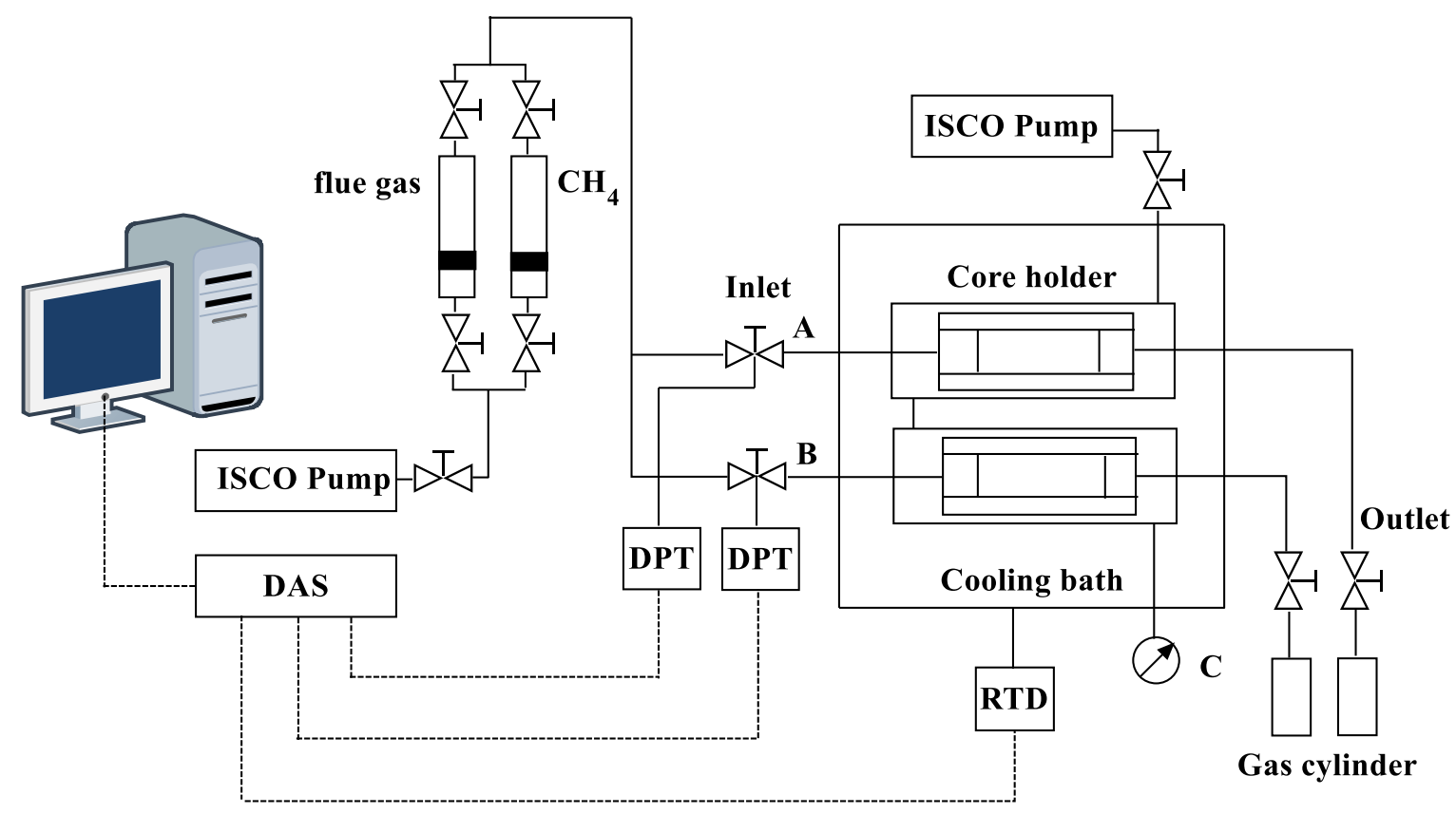

Figure 1. Schematic diagram of the experimental apparatus: RTD, resistance thermocouple detector; DPT, differential pressure transducer; and DAS, data acquisition system.

This study examined the $\mathrm{CH}_{4}$ recovery from hydrate-bearing sandstones by injecting simulated flue gas. A schematic diagram of the experimental setup is shown in Figure 1. The principal parts of the setup are two core holder cylinders with an effective volume of $500 \mathrm{~cm}^{3}$ each, and the maximum 
working pressure is $20 \mathrm{MPa}$. The two core holders are installed in a cooling bath in which a secondary platinum resistance thermometer (type-Pt 100) was used to monitor the temperature. The $\mathrm{CH}_{4}$ and flue gas can be injected into the reactor from the injection cylinders with an electrical ISCO pump. When the swapping reaction was finished, the equilibrium gas can be released through two back-pressure regulators into two gas collection cylinders. The changes of pressure and temperature were collected by the pressure and temperature transducers and recorded in computer. A detailed introduction of the apparatus can be found in our previous publication. ${ }^{37}$

\subsection{Materials.}

$\mathrm{CH}_{4}(99.99 \%), \mathrm{CO}_{2}(99.99 \%)$ and $\mathrm{N}_{2}(99.99 \%)$ were purchased from AGA Gas Company. The simulated flue gas containing $\mathrm{CO}_{2}(19.2 \mathrm{~mol} \%)$ and $\mathrm{N}_{2}(80.8 \mathrm{~mol} \%)$ was prepared by us, the composition of gas mixtures was analyzed by an Agilent gas chromatograph (GC 7890A). $\mathrm{NaCl}$ solution $(3.35 \mathrm{wt} \%)$ was made in the laboratory. The characteristics of sandstones (originated from Germany) are listed in Table 1.

Table 1. Physical Properties of Sandstones used in This Study

\begin{tabular}{cccccccc}
\hline Sandstone & $\begin{array}{c}\text { Diameter } \\
(\mathrm{cm})\end{array}$ & $\begin{array}{c}\text { Length } \\
(\mathrm{cm})\end{array}$ & $\begin{array}{c}\text { Dry weight } \\
(\mathrm{g})\end{array}$ & $\begin{array}{c}\mathrm{D}_{\mathrm{g}} \\
\left(\mathrm{g} \cdot \mathrm{cm}^{-3}\right)\end{array}$ & $\begin{array}{c}\mathrm{D}_{\mathrm{b}} \\
\left(\mathrm{g} \cdot \mathrm{cm}^{-3}\right)\end{array}$ & $\begin{array}{c}\text { Porosity } \\
(\%)\end{array}$ & $\begin{array}{c}\text { Permeability } \\
(\mathrm{mD})\end{array}$ \\
\hline $\mathrm{A}$ & 2.55 & 7.77 & 73.76 & 2.48 & 1.86 & 25.1 & 49 \\
$\mathrm{~B}$ & 2.55 & 7.77 & 79.22 & 2.56 & 2.00 & 22.0 & 44 \\
$\mathrm{C}$ & 2.55 & 7.77 & 82.70 & 2.57 & 2.08 & 19.1 & 37 \\
$\mathrm{D}$ & 2.55 & 7.77 & 85.03 & 2.60 & 2.15 & 17.5 & 31 \\
\hline
\end{tabular}

${ }^{*} \mathrm{D}_{\mathrm{g}}$ and $\mathrm{D}_{\mathrm{b}}$ are the grain density and bulk density, respectively. The porosity and permeability are measured by a steady state gas permeameter and porosimeter, the permeability reported here is Klinkenberg permeability.

\subsection{Method.}




\subsubsection{Experimental Procedure.}

The detailed description of experimental procedure has been reported in our previously study, ${ }^{37}$ here we briefly introduce it as follows: first, the sandstones were cleaned (with toluene and ethanol) and dried, then saturated with brine water and installed into the apparatus. The cooling bath temperature was set to $277.15 \mathrm{~K}$, then injecting $\mathrm{CH}_{4}$ to start the reaction. $\mathrm{CH}_{4}$ hydrate formation can be identified from a sudden pressure drop as shown in Figure 2. After preparing the hydrate-bearing sandstones, the sweep method ${ }^{51}$ was used to purge the free $\mathrm{CH}_{4}$ then pressurize it to $9.0 \mathrm{MPa}$ with flue gas to start the swapping reaction. One thing to note is that, in order to avoid $\mathrm{CH}_{4}$ dissociation in this process, the reactor pressure should be always slightly higher than the equilibrium pressure of $\mathrm{CH}_{4}$ hydrate at $277.15 \mathrm{~K}$. The flue gas was replenished for improving the $\mathrm{CH}_{4}$ recovery. After the swapping experiment was finished, the equilibrium gas was analyzed by GC. Typical pressure and temperature changes in the $\mathrm{CH}_{4}$-flue gas swapping was shown in Figure 3.

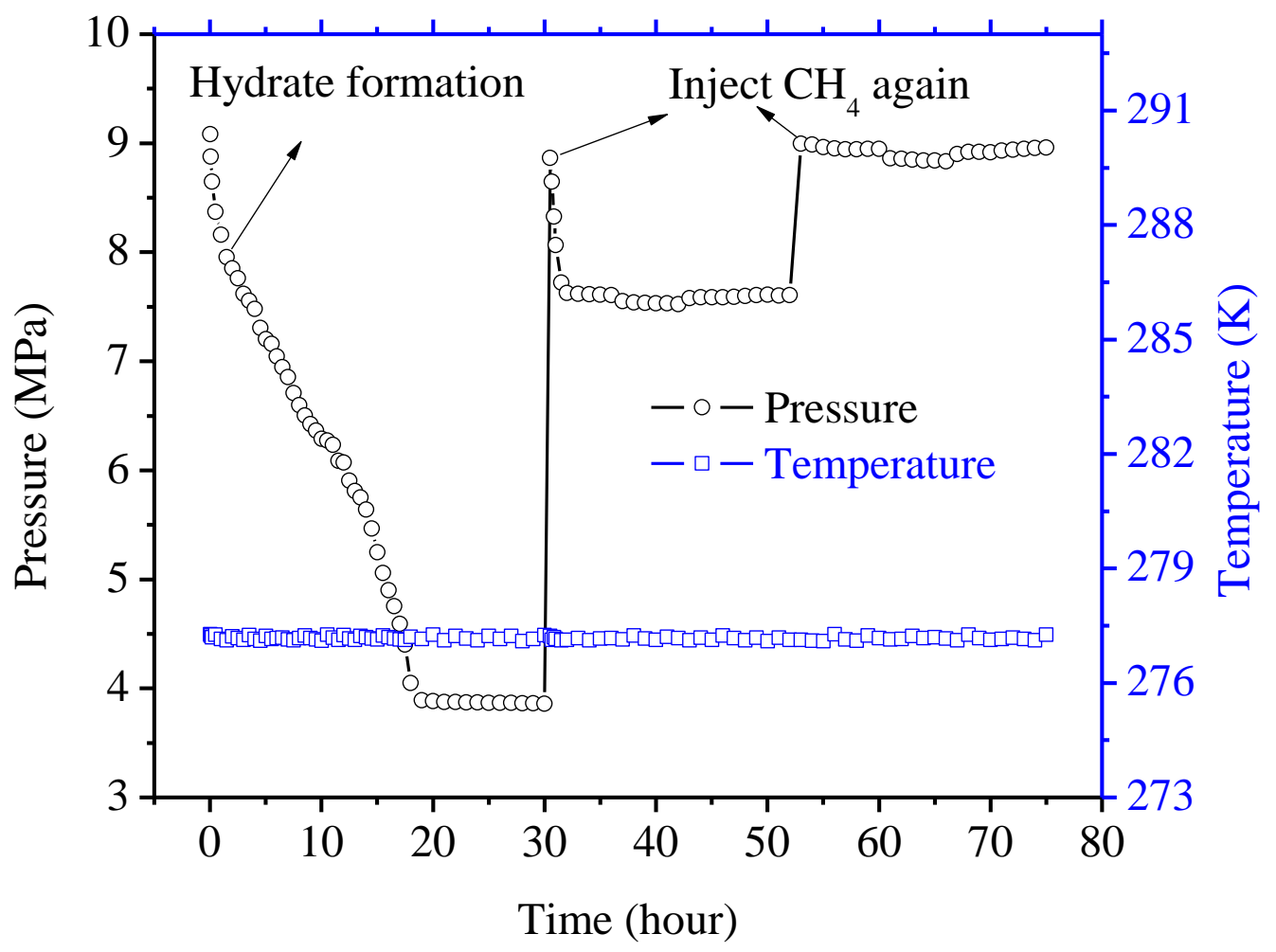

Figure 2. Pressure and temperature changes in $\mathrm{CH}_{4}$ hydrate formation. 


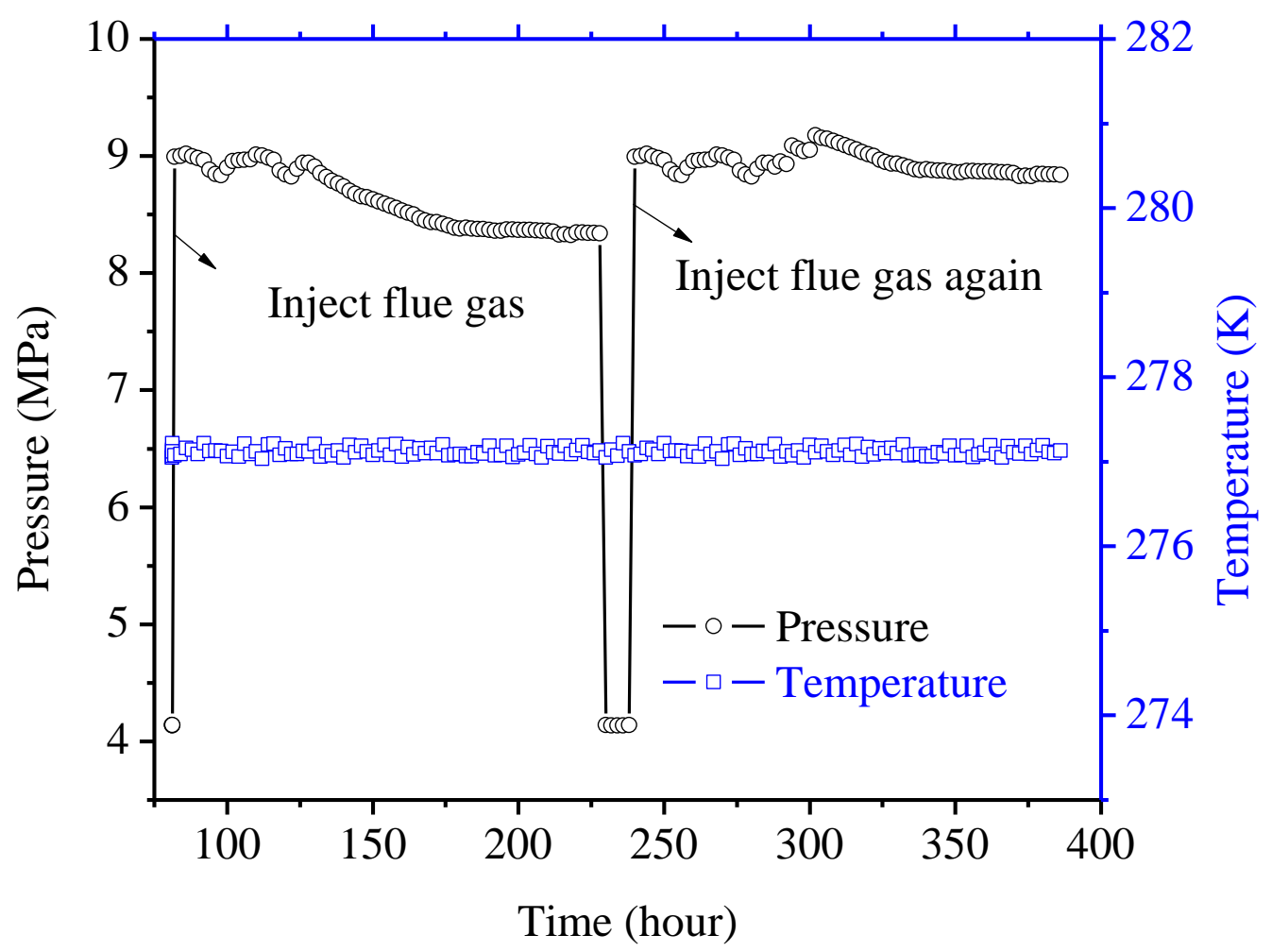

Figure 3. Pressure and temperature changes in $\mathrm{CH}_{4}$-flue gas swapping.

\subsubsection{Data Processing.}

The mole number of $\mathrm{CH}_{4}$ trapped in hydrate phase $\left(n_{\mathrm{CH}_{4}, \mathrm{H}}\right)$ can be calculated by:

$$
n_{\mathrm{CH}_{4}, \mathrm{H}}=\frac{\Delta P V}{Z R T}
$$

Where $\Delta P$ is the pressure changes in $\mathrm{CH}_{4}$ hydrate formation, $V$ is the effective gas phase volume of the reactor, $Z$ is the compressibility factor and can be calculated by BWRS equation of state, ${ }^{38} R$ is the universal gas constant, $T$ is the cooling bath temperature. The changes of dissolved gas in water phase at different pressures can be calculated by Henry's law, however, it can be ignored here since less water existed in the sandstones. The amount of water converted to hydrate can be calculated with a hydrate number $6.0,{ }^{39}$ then the corresponding water saturation $\left(S_{\mathrm{w}}\right)$, hydrate saturation $\left(S_{\mathrm{H}}\right)$ and gas saturation $\left(S_{\mathrm{G}}\right)$ can be obtained. Similarly, the mole number of $\mathrm{CH}_{4}$ recovered $\left(n_{\mathrm{CH}_{4}, \mathrm{Re}}\right)$ as well as $\mathrm{CO}_{2}$ or $\mathrm{N}_{2}$ captured $\left(n_{\mathrm{CO}_{2}, \mathrm{H}}, n_{\mathrm{N}_{2}, \mathrm{H}}\right)$ in the swapping process can also be determined by 
equation (1) when obtained the composition of equilibrium gas from GC as well as the pressure changes in reaction. The $\mathrm{CH}_{4}$ recovery efficiency is defined as:

$$
R_{\mathrm{CH}_{4}}=\frac{n_{\mathrm{CH}_{4}, \mathrm{Re}}}{n_{\mathrm{CH}_{4}, \mathrm{H}}} \times 100 \%
$$

The detailed calculation procedure can refer to our previous articles. ${ }^{37}$

\section{Results and discussion}

\subsection{Properties of synthesized hydrate-bearing sandstones.}

Based on the location of hydrate layer as well as the free gas and water, there are mainly three typical hydrate reservoirs in nature: ${ }^{40}$ Class 1 , hydrate layer located underneath two-phase zone of free gas and water; Class 2, hydrate layer formed under one-phase zone of free water (no gas); Class 3 , hydrate layer with no free fluids coexisting. Class 1 is theoretically the most suitable for hydrate exploitation, since it is thermodynamically close to the hydrate equilibrium condition. However, the $\mathrm{CH}_{4}$-flue gas swapping for the Class 1 and 2 would be not easy because the flue gas will firstly form new hydrates with the free water and affect the reaction rate. Therefore, we mainly synthesized hydrate samples resembling the situation in Class 3 in this work, focusing on how hydrate saturation as well as the initial porosity and permeability of sandstone affect the $\mathrm{CH}_{4}$ recovery in swapping. The properties of the synthesized hydrate-bearing sandstone samples are listed in Table 2, and the sandstones A, B, C and D used here have the same cross-sectional area and length. In this study, we prepared the $\mathrm{CH}_{4}$ hydrate-bearing sandstones with different hydrate saturations: (i) the higher hydrate saturation case (Run 1, 2, 5, 6, 7), where an annealing process was used to improve water conversion. This is done by raising and lowering the experimental temperature repeatedly, making sure the gas hydrates experience at least one cycle of dissociation and re-formation. The pressure and temperature curves measured during the annealing process in experimental run 2 and 1 are plotted in Figure 4 and 5, respectively, which correspond to two 
different cases in the annealing process. As shown in Figure 4, the pressures have little difference before and after annealing, which suggests no more extra hydrate formed and redistributed in experimental run 2. However, Figure 5 shows that the system pressure after the annealing process fells to a lower value than before, which indicates more methane molecules trapped in the hydrate phase in the case of experimental run 1. It can be seen that the annealing process enhances the overall hydrate formation yield. One reason for this may be the inhomogeneous initial hydrate distribution in the sandstone where there is an amount of free water remaining unreacted in the first hydrate formation process. The annealing process dissociates and reforms the hydrate thereby increasing water conversion. In addition, the pressure and temperature curves of Run 5, 6 and 7 are more like Figure 4 (which is the case of Run 2), the reason might be that the hydrate saturation of sandstones in Run 5, 6 and 7 are basically the same with that in the Run 2. (ii) Experiments were also performed with a lower hydrate saturation (Run 3 and 4) case, in which only the initial $\mathrm{CH}_{4}$ hydrate formation was performed and an annealing was not conducted.

Table 2. Properties of Synthesized $\mathrm{CH}_{4}$ Hydrate-bearing Sandstones

\begin{tabular}{ccccccccc}
\hline Run & Sandstone & $\begin{array}{c}\text { Temperature } \\
(\mathrm{K})\end{array}$ & $\begin{array}{c}\text { Pressure }^{*}(\mathrm{MPa}) \\
\mathrm{m}^{2}\end{array}$ & $\begin{array}{c}m_{\mathrm{H}_{2} \mathrm{O}} \\
(\mathrm{g})\end{array}$ & $\begin{array}{c}n_{\mathrm{CH}_{4}, \mathrm{H}} \\
(\mathrm{mmol})\end{array}$ & $\begin{array}{c}S_{\mathrm{W}} \\
(\%)\end{array}$ & $\begin{array}{c}S_{\mathrm{H}} \\
(\%)\end{array}$ & $\begin{array}{c}S_{\mathrm{G}} \\
(\%)\end{array}$ \\
\hline 1 & A & 277.15 & 9.04 & 7.05 & 59.6 & 6.3 & 82.5 & 11.2 \\
3 & A & 277.15 & 9.13 & 7.02 & 53.0 & 13.3 & 73.7 & 13.0 \\
4 & A & 277.15 & 9.14 & 7.03 & 44.5 & 22.9 & 61.8 & 15.3 \\
5 & A & 277.15 & 9.14 & 7.08 & 34.7 & 34.4 & 48.2 & 17.4 \\
6 & B & 277.15 & 9.12 & 7.01 & 52.3 & 14.0 & 72.4 & 13.6 \\
7 & D & 277.15 & 9.07 & 6.99 & 41.0 & 13.9 & 72.6 & 13.5 \\
\hline
\end{tabular}

*The initial pressure after injecting $\mathrm{CH}_{4}$. 


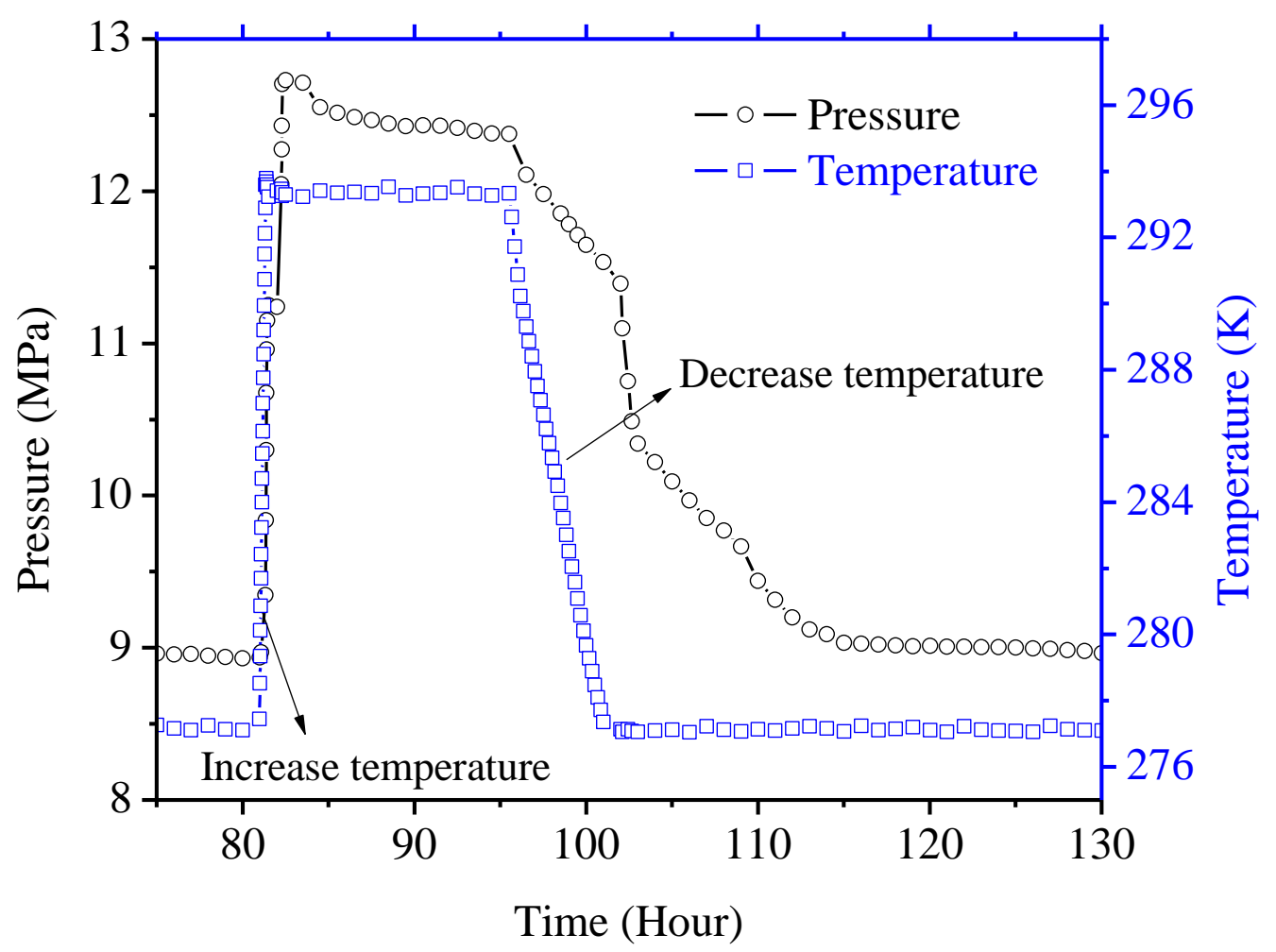

Figure 4. Pressure and temperature changes during the annealing process in experimental run 2.

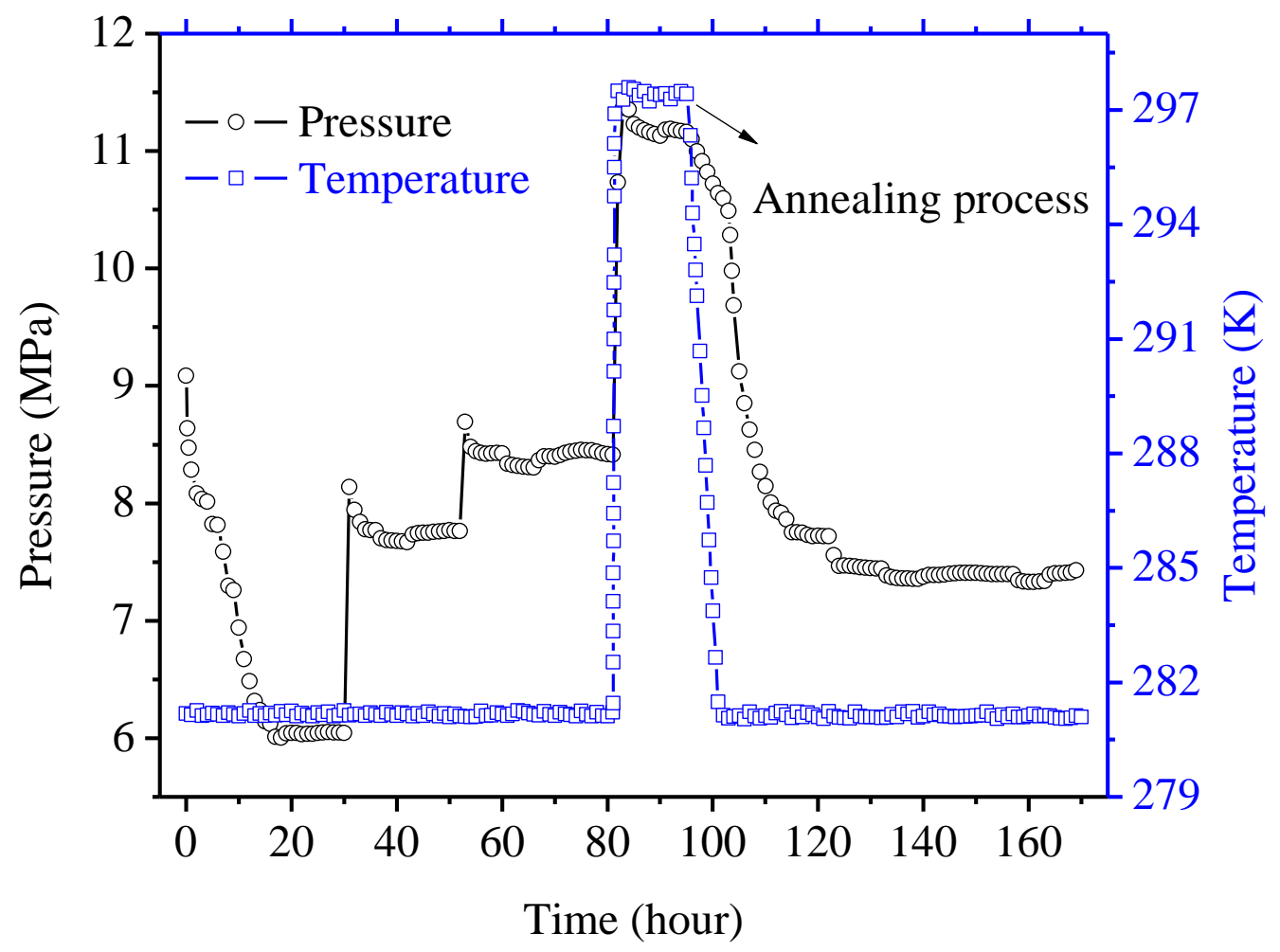

Figure 5. Pressure and temperature changes during the annealing process in experimental run 1. 


\subsection{The effect of hydrate saturation on the swapping process.}

For studying the swapping behavior of flue gas in $\mathrm{CH}_{4}$ hydrate-bearing sandstones, seven tests were conducted and the results are listed in Table 3. In this work, we used the same sandstone (A) to form gas hydrate four times to test the influence of hydrate saturation on the $\mathrm{CH}_{4}$ recovery efficiency in the swapping process in order to ensure the same initial porosity and permeability. It has been reported that Alaska site test is distinguished by a higher hydrate saturation (around $75 \%),{ }^{41}$ therefore the sample in Run 2 was prepared with similar hydrate saturation. From the properties of synthesized methane hydrate-bearing sandstone samples, it can be seen that the low $S_{\mathrm{H}}$ system has a relatively large amount of free water, and the water saturation in hydrate-bearing sandstones samples increases with the decreasing of hydrate saturation. Some researchers ${ }^{29,51}$ believe that the excess water in the system can affect the replacement reaction rate and lower the mass transfer efficiency since it causes the formation of $\left(\mathrm{CO}_{2}+\mathrm{N}_{2}\right)$ mixed gas hydrates. In our study, it was observed that the $\mathrm{CH}_{4}$ recovery efficiency increases with increasing hydrate saturation when other experimental conditions are similar, as shown in Figure 6. In addition, the amount of $\mathrm{CO}_{2}$ captured also increases with increasing hydrate saturation, which suggests that there are more $\mathrm{CO}_{2}$ molecules replacing $\mathrm{CH}_{4}$ in hydrate cages under high hydrate saturation conditions. The reason for the results might be that, there are less free water in the sandstones with a higher hydrate saturation, which makes the $\mathrm{CO}_{2}$ molecules can more immediately swap with $\mathrm{CH}_{4}$ molecules in the hydrate phase. In the case of lower hydrate saturation sandstones, the $\mathrm{CO}_{2}$ molecules probably first form new $\mathrm{CO}_{2}$ hydrate with free water, which would increase the mass transfer resistance to some extent. Although the reaction with free water can consume a portion of $\mathrm{CO}_{2}$ and increase the amount of $\mathrm{CO}_{2}$ capture, it would decrease the concentration of $\mathrm{CO}_{2}$ in gas phase and cannot contribute to increasing the $\mathrm{CH}_{4}$ recovery efficiency. Here we obtained the highest recovery efficiency of $51.6 \%$ 
at a hydrate saturation of $82.5 \%$, about $99.4 \%$ of $\mathrm{CO}_{2}$ in simulated flue gas is sequestered in the hydrate phase after swapping. This result is very close to the result in Lee's work, ${ }^{27}$ where they test the $\mathrm{CH}_{4}$-flue gas swapping with a one-dimensional reactor and the $\mathrm{CH}_{4}$ recovery efficiency is $49 \%$.

Table 3. Experimental Conditions and Results for $\mathrm{CH}_{4}$-flue gas Swapping

\begin{tabular}{cccccccc}
\hline Run & Sandstone & $\begin{array}{c}\text { Temperature } \\
(\mathrm{K})\end{array}$ & $\begin{array}{c}\text { Pressure } \\
(\mathrm{MPa})\end{array}$ & $\begin{array}{c}n_{\mathrm{CH}_{4}, \mathrm{Re}} \\
(\mathrm{mmol})\end{array}$ & $\begin{array}{c}n_{\mathrm{CO}_{2}, \mathrm{H}} \\
(\mathrm{mmol})\end{array}$ & $\begin{array}{c}n_{\mathrm{N}_{2}, \mathrm{H}} \\
(\mathrm{mmol})\end{array}$ & $R_{\mathrm{CH}_{4}}$ \\
\hline 1 & A & 277.15 & 9.18 & 30.8 & 20.4 & 10.4 & 51.6 \\
2 & A & 277.15 & 9.08 & 26.4 & 19.9 & 8.6 & 49.7 \\
3 & A & 277.15 & 9.14 & 21.0 & 16.1 & 6.9 & 47.1 \\
4 & A & 277.15 & 8.94 & 16.1 & 15.4 & 2.6 & 46.3 \\
5 & B & 277.15 & 9.05 & 24.5 & 19.6 & 6.6 & 46.8 \\
6 & C & 277.15 & 8.98 & 22.4 & 17.9 & 5.7 & 42.9 \\
7 & D & 227.15 & 8.98 & 21.5 & 15.9 & 4.5 & 41.0 \\
\hline
\end{tabular}

*The equilibrium pressure after flue gas swapping.

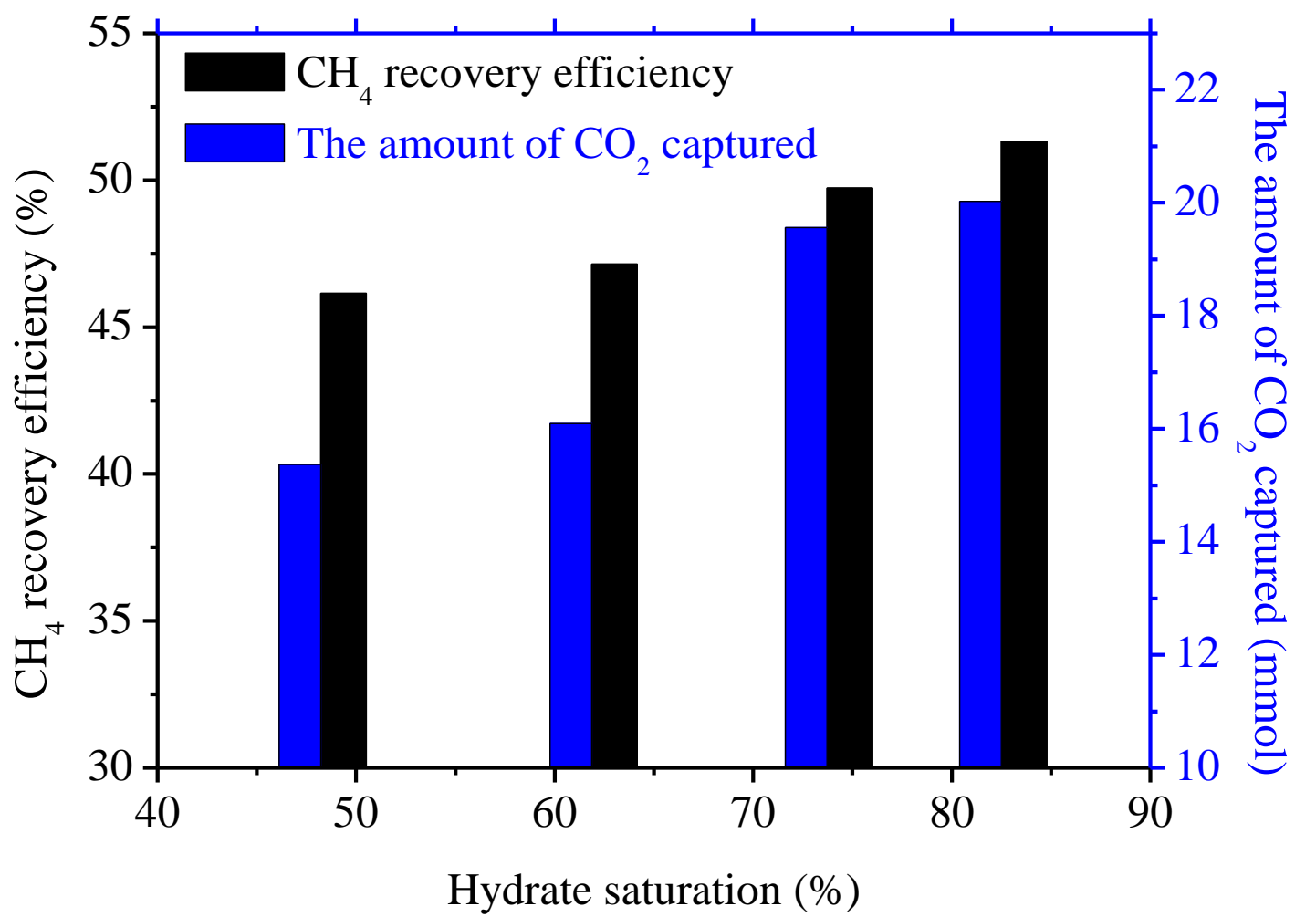

Figure 6. Methane recovery efficiency and the amount of $\mathrm{CO}_{2}$ captured at different hydrate saturation. 


\subsection{The effect of porosity and permeability on the $\mathrm{CH}_{4}$-flue gas swapping process.}

To investigate how the porosity and permeability of sandstone affect the methane production and $\mathrm{CO}_{2}$ capture during the swapping reaction, four tests were performed at the condition of identical hydrate saturation (around 73\%). The porosity of sandstones A, B, C and D used here (corresponding to experimental run 2, 5, 6 and 7, respectively) are 25.1\%, 22.0\%, $19.1 \%$ and 17.5\%, their permeability are $49,44,37$ and $31 \mathrm{mD}$, respectively. One thing to note is that the porosity and permeability of sandstone in this work refer to that of the original sandstones, since it is difficult to measure that of the hydrate-bearing sandstones. Our previous experimental investigation showed that the $\mathrm{CH}_{4}-\mathrm{CO}_{2}$ swapping reaction process in hydrate bearing sandstones is significantly affected by the mass transfer of diffusion and the driving force. ${ }^{37}$ Since the diffusion efficiency and driving force for the swapping reaction mainly depend on the $\mathrm{CO}_{2}$ concentration gradient in the gas and hydrate phase, the decreasing $\mathrm{CO}_{2}$ concentration with elapsed time during the swapping process would lower the mass transfer efficiency and reaction rate. In view of this situation, the limitations in mass transfer and replacement efficiency were addressed by many researchers by injecting swapping gas continuously to maintain a high $\mathrm{CO}_{2}$ concentration in the system and keep a constant

driving force, ${ }^{27}$ however, this method to some extent would inevitably lead to $\mathrm{CO}_{2}$ emission and increase gas recycling and separation cost in field scale production. In this work, we used a batch operation method that uses the flue gas to purge the free $\mathrm{CH}_{4}$ before starting each swapping experiment, then replenishing the reactor with fresh flue gas once the reaction was assumed to be stopped due to lack of a driving force. The swapping process of experimental run 2, 5, 6 and 7 lasted 240 hours in all, after which the equilibrium gas was sampled and analyzed, the experimental results are shown in Figure 7 and 8, respectively. From Figure 7, it can be seen that the $\mathrm{CH}_{4}$ recovery efficiency and amount of $\mathrm{CO}_{2}$ captured increases with increasing sandstone porosity, which indicates that a higher porosity is beneficial to mass transfer and gas production. The effect 
of permeability on $\mathrm{CH}_{4}$ recovery efficiency and amount of $\mathrm{CO}_{2}$ captured has the same trend. These results confirmed that the sandstone's porosity and permeability are important influence factors in $\mathrm{CH}_{4}$-flue gas swapping. Figure 9 compares the $\mathrm{CH}_{4}$ productivity in each experimental run, here it is the $\mathrm{CH}_{4}$ average production rate per hour. It can be seen that, methane production rate decreases as the permeability decreases (the permeability of sandstones in run 2, 5, 6 and 7 are 49, 44, 37 and 31 $\mathrm{mD}$, respectively). Especially, run 2, which has the highest permeability, resulted in a methane production rate $7.8-22.9 \%$ higher than that of runs 5,6 , and 7 . In addition, the methane productivity also present a decreasing trend with decreasing hydrate saturation (the hydrate saturation of sandstones in run 1, 2, 3 and 4 are $82.5 \%, 73.7 \%, 61.8 \%$ and $48.2 \%$, respectively).

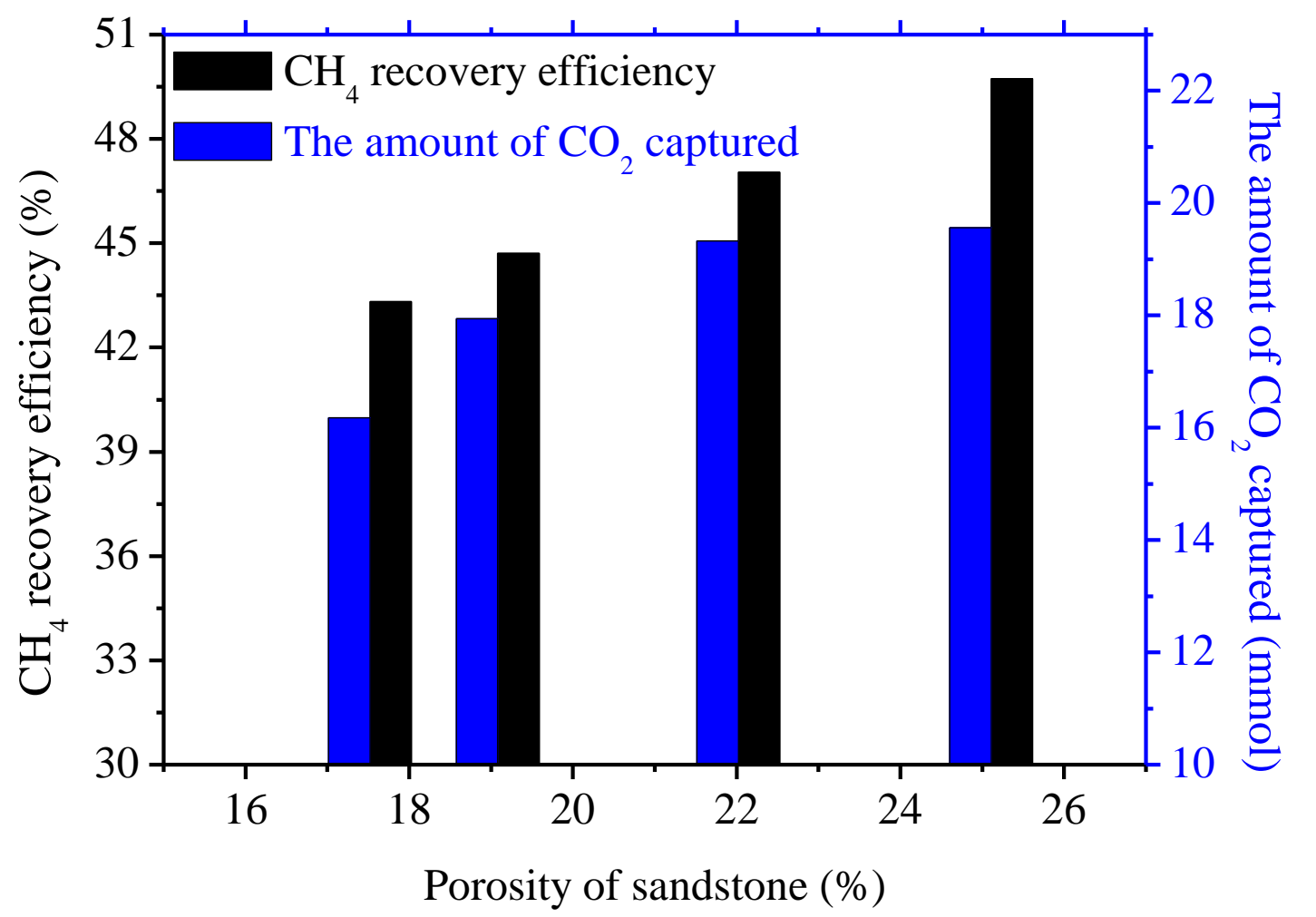

Figure 7. Methane recovery efficiency and the amount of $\mathrm{CO}_{2}$ captured at different porosity of sandstones. 


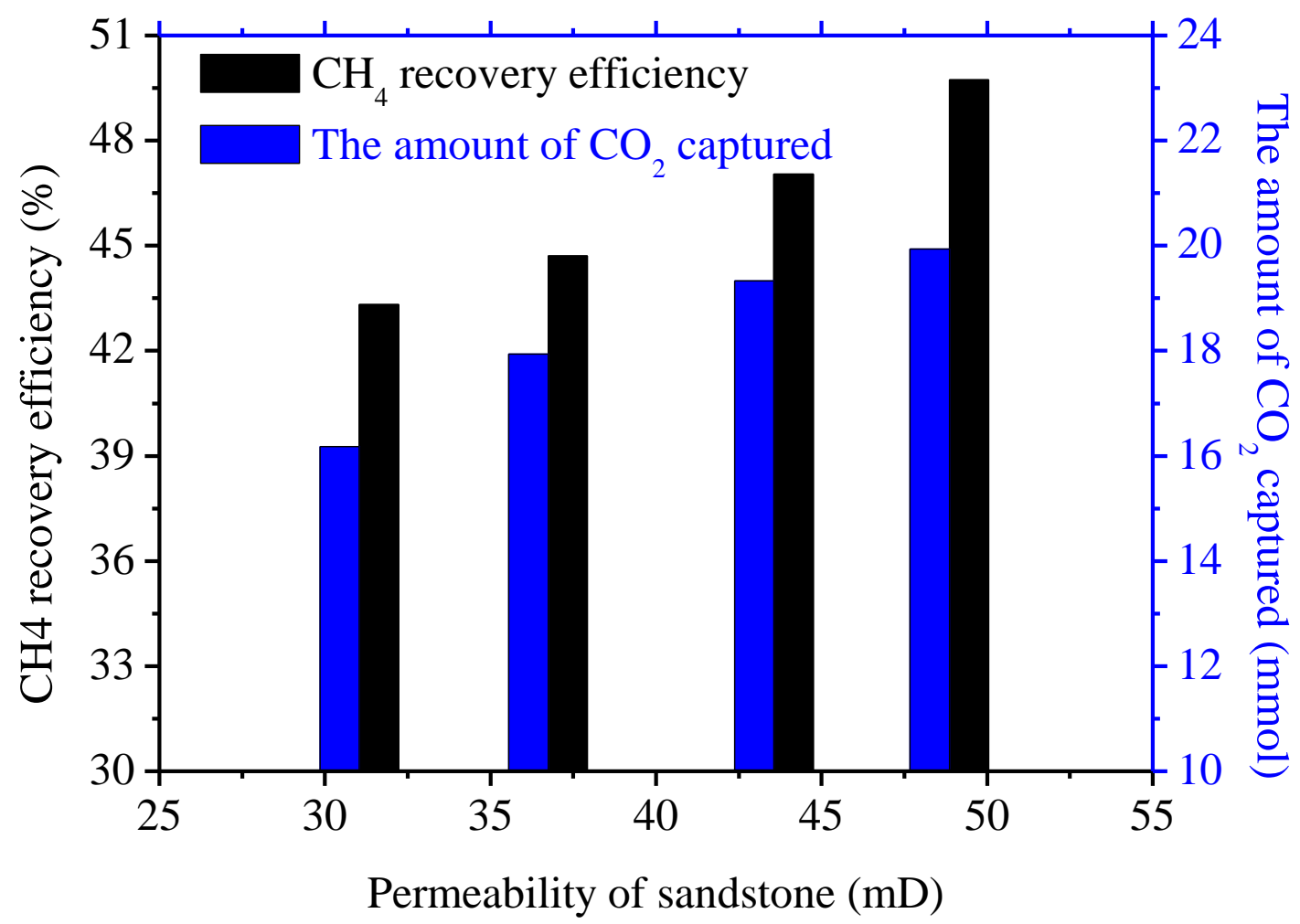

Figure 8. Methane recovery efficiency and the amount of $\mathrm{CO}_{2}$ captured at different permeability of sandstones.

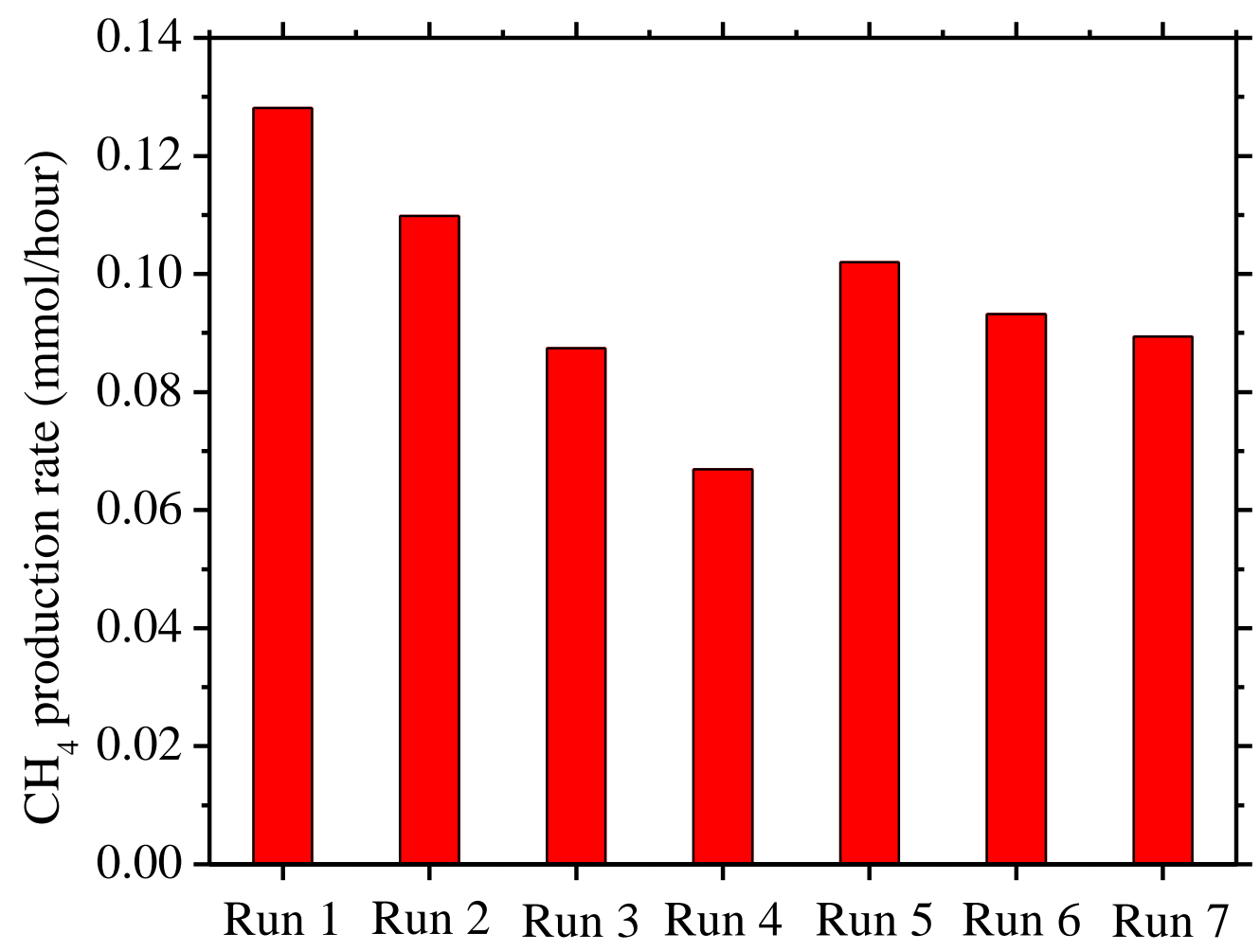


Figure 9. The average methane production rate in each experimental run.

3.4. Reaction heat investigation of $\mathrm{CH}_{4}$-flue gas swapping with DSC apparatus.

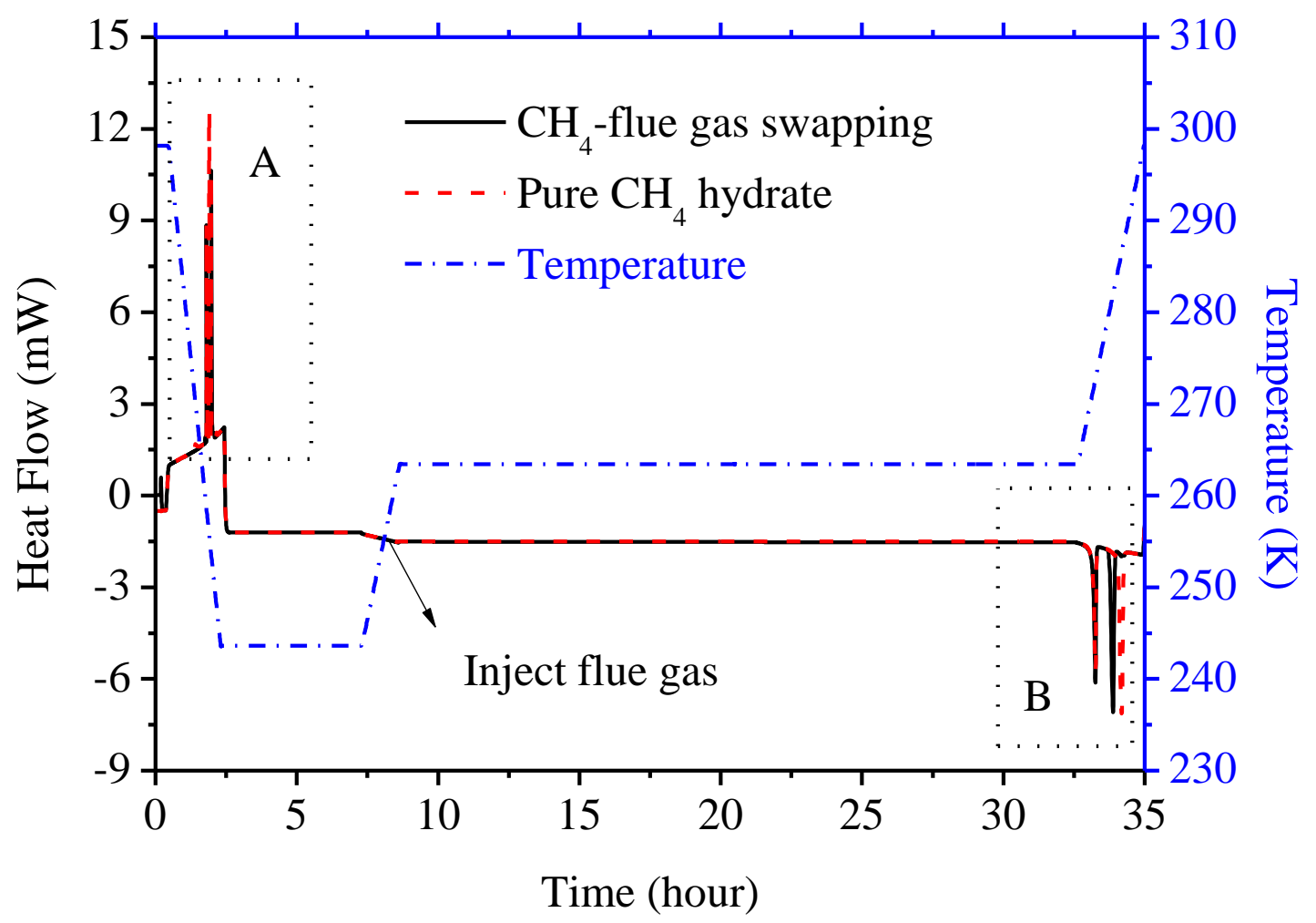



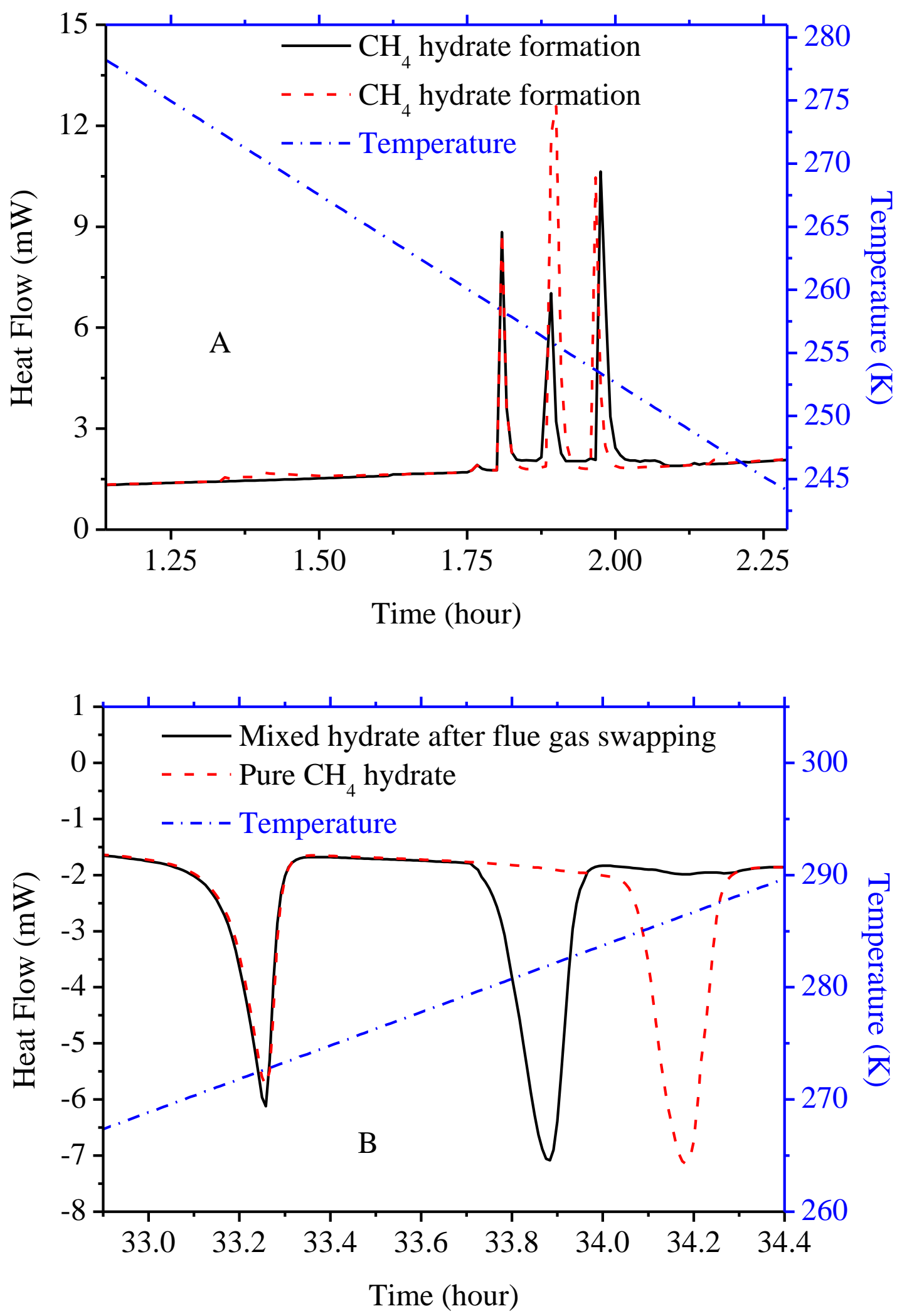

Figure 10. Heat flow changes in brine obtained during methane hydrate formation (A), flue gas swapping and dissociation $(\mathrm{B})$. 
In this study, it was observed that the reaction rate of $\mathrm{CH}_{4}$-flue gas swapping is low, and we infer that the reaction process was mainly controlled by mass transfer, because $\mathrm{CO}_{2}$ molecules would diffuse along its concentration gradient in the hydrate-bearing sandstones and penetrate the already formed $\mathrm{CO}_{2}$ hydrate outer layer to reach the unreacted $\mathrm{CH}_{4}$ hydrate. For studying whether the heat transfer would affect the $\mathrm{CH}_{4}$-flue gas swapping, a micro differential scanning calorimetry ( $\mu$-DSC) was used to test the whole process. Three capillary tubes loaded with around $3.0 \mathrm{mg}$ salt water (3.35 $\mathrm{wt} \% \mathrm{NaCl}$ ) were placed inside the sample cell, the temperature procedure as follows: first, cooling from $298.15 \mathrm{~K}$ to $243.15 \mathrm{~K}$ at $0.5 \mathrm{~K} \cdot \mathrm{min}^{-1}$, then keeping constant at $243.15 \mathrm{~K}$ for 5 hours after which heating from $243.15 \mathrm{~K}$ to $263.15 \mathrm{~K}$ at $0.25 \mathrm{~K} \cdot \mathrm{min}^{-1}$, subsequently, injecting flue gas and keeping constant at $263.15 \mathrm{~K}$ for 24 hours after that heating to $293.15 \mathrm{~K}$ at $0.25 \mathrm{~K} \cdot \mathrm{min}^{-1}$ to dissociate the hydrate. The specific operation of $\mu$-DSC experiments can refer to our previous study. ${ }^{42}$ One thing to note is that, in order to prevent hydrate dissociation when releasing the free $\mathrm{CH}_{4}$ gas and injecting with flue gas, the sample cell pressure should be maintained slightly higher than the hydrate equilibrium pressure at $263.15 \mathrm{~K}$. Figure 10 shows the heat flow curves in $\mathrm{CH}_{4}$ hydrate formation, flue gas swapping and hydrate dissociation at 9.0 MPa. The three exothermic peaks in cooling cycle indicated $\mathrm{CH}_{4}$ hydrate formation (Figure $10 \mathrm{~A}$ ), the reason of forming more than one exothermic peak might be that the capillary tubes are separated and the nucleation cannot affect each other. The endothermic peak at $273.15 \mathrm{~K}$ in heating cycle suggests ice melting and another denotes hydrate dissociation. No peaks detected in the $\mathrm{CH}_{4}$-flue gas swapping and the heat flow changes are constant, which demonstrated the $\mathrm{CH}_{4}$-flue gas swapping proceeds without significant exothermic or endothermic phenomenon. It can be inferred that the $\mathrm{CH}_{4}$ hydrate structure might not be completely destroyed or collapsed in the $\mathrm{CH}_{4}$-flue gas swapping, and $\mathrm{CO}_{2}$ molecules are likely to take the place of $\mathrm{CH}_{4}$ molecules in a peaceful way in the hydrate cage. In heating cycle, the endothermic peak of the mixed hydrates after swapping present a distinct shift 
with that of pure $\mathrm{CH}_{4}$ hydrate, which suggests the hydrate phase composition has changed remarkably. The reason might be $\mathrm{CO}_{2}$ molecules have already replaced a portion of $\mathrm{CH}_{4}$ molecules in hydrate cage and formed $\left(\mathrm{CO}_{2}+\mathrm{CH}_{4}\right)$ mixed hydrates, the new formed hydrates showed different dissociation temperature and endothermic peak position at the same pressure and heating rate.

Based on our investigation in this study and previous research results in literature, ${ }^{43-48}$ we infer the mechanism on $\mathrm{CH}_{4}$-flue gas swapping as follows: Firstly, the $\mathrm{CO}_{2}$ molecules will destroy the stability of methane hydrate structure due to the difference of chemical potential, especially the large cages in sI hydrate will be firstly destabilized under the action of $\mathrm{CO}_{2}$ molecules. Some researchers believed that the destroyed cages are mainly large $\left(5^{12} 6^{2}\right)$ cages, while small $\left(5^{12}\right)$ cages can be maintained for a longer time, because large cages have some unfavorable angles of $\mathrm{H}_{2} \mathrm{O}$ molecules for the planar hexagonal rings. ${ }^{49,50}$ Secondly, the large cages will distort and the $\mathrm{CH}_{4}$ molecules trapped inside are released. It should be noted that this process will leave plentiful hydrate residual rings which retain most of the hydrogen bonding energy and facilitate the process of $\mathrm{CO}_{2}$ molecules being trapped in hydrate cages and enhancing the dynamic process. In addition, this is also the reason that we did not observe obvious endothermic and exothermic peaks in the process of swapping by $\mu$-DSC test. Finally, the small cages will be unstable and liberate $\mathrm{CH}_{4}$ molecules while being filled with $\mathrm{N}_{2}$ molecules after most $\mathrm{CO}_{2}$ molecules have been enclosed in the large cages. It can be concluded that the $\mathrm{CH}_{4}$-flue gas in hydrate-bearing sandstones is mainly influenced by mass transfer since there is no significant heat phenomenon in the swapping process, larger porosity and permeability of sandstones will be beneficial to methane production using swapping method. However, this doesn't mean that the factors involving heat transfer is not worth considering in the swapping process, Zhao et al. ${ }^{52-54}$ did a series of studies on $\mathrm{CH}_{4}$ recovery from gas hydrate by depressurization, nitrogen injection as well as $\mathrm{CO}_{2}$ swap method, they believed that the sensible heat of the reservoir and ambient heat transfer have a significant influence on hydrate 
dissociation. Therefore, the investigation of mechanism of $\mathrm{CH}_{4}$-flue gas swapping is an on-going process of great significance, in which both experimental and simulation studies are necessary in the future research.

\section{Conclusions}

A core flooding setup was used to test $\mathrm{CH}_{4}$ recovery from artificial hydrate-bearing sandstones by injecting simulated flue gas. Seven experimental runs were performed to examine the influence of hydrate saturation as well as the initial porosity and permeability of sandstones on methane production and carbon dioxide capture. The experimental results indicated that the $\mathrm{CH}_{4}$ recovery efficiency and the amount of $\mathrm{CO}_{2}$ captured increase with the increased hydrate saturation at the identical initial porosity and permeability of sandstone. The highest $\mathrm{CH}_{4}$ recovery efficiency obtained here is $51.6 \%$ at $9.2 \mathrm{MPa}$ and $277.15 \mathrm{~K}$ under the condition of hydrate saturation of $82.5 \%$ with the initial porosity and permeability of sandstone are $25.1 \%$ and $49 \mathrm{mD}$, respectively, while $99.4 \%$ of $\mathrm{CO}_{2}$ in simulated flue gas is sequestered in the hydrate phase after swapping. With increasing initial porosity and permeability of sandstone, the $\mathrm{CH}_{4}$ recovery efficiency and the amount of $\mathrm{CO}_{2}$ captured increase at the same hydrate saturation and reaction time. For exploring the swapping mechanism of $\mathrm{CH}_{4}$-flue gas, a high pressure $\mu$-DSC apparatus was used to test the heat changes in the whole reaction, no obviously thermal phenomenon were observed in the $\mathrm{CH}_{4}$-flue gas swapping, which indicated that $\mathrm{CH}_{4}$ hydrate would form mixed hydrates directly instead of undergoing a dissociation and reformation procedure. Based on the observed experimental results, the $\mathrm{CH}_{4}$-flue gas swapping mechanism was proposed: firstly, the hydrate cage would be distorted to release $\mathrm{CH}_{4}$ molecules, and the hydrate residual cage structure can promote $\mathrm{CO}_{2}$ hydrate nucleation and enhance its dynamic process. With the swapping proceeding, the outer layer hydrate slows down the mass transfer and $\mathrm{CH}_{4}$-flue gas swapping rate. In addition, the decrease of porosity and 
permeability of sandstones reduces the diffusion rate of $\mathrm{CO}_{2}$ along concentration gradient from outer layer to inner layer, making it more difficult for $\mathrm{CO}_{2}$ molecules to reach the unreacted $\mathrm{CH}_{4}$ hydrate. It is concluded that the $\mathrm{CH}_{4}$-flue gas swapping process was essentially controlled by mass transfer in sandstones.

\section{AUTHOR INFORMATION}

\section{Corresponding Author}

*Telephone: +45 4525 2867. Fax: +45 4588 2258. E-mail: nvs@kt.dtu.dk (N. von Solms).

\section{REFERENCES}

(1) Sloan, E. D.; Koh, C. A. Clathrate Hydrates of Natural Gases, 3rd ed.; CRC Press, Taylor \& Francis Group: Boca Raton, FL,2008.

(2) Sloan, E. D.; Koh, C. A.; Sum, A. Natural gas hydrates in flow assurance. Burlington: Access Online via Elsevier, 2010.

(3) Makogon, Y. F. Natural gas hydrates-A promising source of energy. J. Nat. Gas Sci. Eng. 2010, 2 (1), 49-59.

(4) Boswell, R.; Collett, T. S. Current perspectives on gas hydrate resources. Energy Environ. Sci. 2011, 4, 1206-1215.

(5) Collett, T.; Bahk, J. J.; Baker, R.; Boswell, R.; Divins, D.; Frye, M.; Goldberg, D.; Husebø, J.; Koh, C.; Malone, M.; Morell, M.; Myers, G.; Shipp, C.; Torres, M. Methane Hydrates in NatureCurrent Knowledge and Challenges. J. Chem. Eng. Data 2015, 60 (2), 319-329. 
(6) Tohidi, B.; Anderson, R.; Clennell, M. B.; Burgass, W. R.; Biderkab, A. B. Visual Observation of Gas-Hydrate Formation and Dissociation in Synthetic Porous Media by Means of Glass Micromodels. Geology 2001, 29 (9), 867-870.

(7) Tang, L. G.; Xiao, R.; Huang, C.; Feng, Z. P.; Fan, S. S. Experimental Investigation of Production Behavior of Gas Hydrate under Thermal Stimulation in Unconsolidated Sediment. Energy Fuels 2005, 19 (6), 2402-2407.

(8) Li, X. S.; Wan, L. H.; Li, G.; Li, Q. P.; Chen, Z. Y.; Yan, K. F. Experimental Investigation into the Production Behavior of Methane Hydrate in Porous Sediment with Hot Brine Stimulation. Ind. Eng. Chem. Res. 2008, 47 (23), 9696-9702.

(9) Linga, P.; Haligva, C.; Nam, S. C.; Ripmeester, J. A.; Englezos, P. Recovery of Methane from Hydrate Formed in a Variable Volume Bed of Silica Sand Particles. Energy Fuels 2009, 23 (11), $5508-5516$.

(10) Tonnet, N.; Herri, J. M. Methane hydrates bearing synthetic sediments-Experimental and numerical approaches of the dissociation. Chem. Eng. Sci. 2009, 64 (19), 4089-4100.

(11) Yang, X.; Sun, C. Y.; Yuan, Q.; Ma, P. C.; Chen, G. J. Experimental Study on Gas Production from Methane Hydrate-Bearing Sand by Hot-Water Cyclic Injection. Energy Fuels 2010, $24(11), 5912-5920$.

(12) Moridis, G. J.; Sloan, E. D. Gas production potential of disperse low-saturation hydrate accumulations in oceanic sediments. Energy Convers. Manage. 2007, 48 (6), 1834-1849.

(13) Seol, Y.; Myshakin, E. Experimental and Numerical Observations of Hydrate Reformation during Depressurization in a Core-Scale Reactor. Energy Fuels 2011, 25 (3), 1099-1110. 
(14) Yang, X.; Sun, C. Y.; Su, K. H.; Yuan, Q.; Li, Q. P.; Chen, G. J. A three-dimensional study on the formation and dissociation of methane hydrate in porous sediment by depressurization. Energy Convers. Manage. 2012, 56, 1-7.

(15) Oyama, H.; Konno, Y.; Suzuki, K.; Nagao, J. Depressurized dissociation of methanehydrate-bearing natural cores with low permeability. Chem. Eng. Sci. 2012, 68 (1), 595-605.

(16) Kumar, A.; Maini, B.; Bishnoi, P. R.; Clarke, M. Investigation of the Variation of the Surface Area of Gas Hydrates during Dissociation by Depressurization in Porous Media. Energy Fuels 2013, $27(10), 5757-5769$.

(17) Li, B.; Li, X. S.; Li, G.; Feng, J. C.; Wang, Y. Depressurization induced gas production from hydrate deposits with low gas saturation in a pilot-scale hydrate simulator. Appl. Energy 2014, 129, 274-286.

(18) Li, G.; Li, X. S.; Tang, L G.; Zhang, Y. Experimental Investigation of Production Behavior of Methane Hydrate under Ethylene Glycol Injection in Unconsolidated Sediment. Energy Fuels 2007, $21(6), 3388-3393$.

(19) Yuan, Q.; Sun, C. Y.; Yang, X.; Ma, P. C.; Ma, Z. W; Li, Q. P.; Chen, G. J. Gas Production from Methane-Hydrate-Bearing Sand by Ethylene Glycol Injection Using a Three-Dimensional Reactor. Energy Fuels 2011, 25 (7), 3108-3115.

(20) Park, Y.; Kim, D. Y.; Lee, J. W.; Huh, D. G.; Park, K. P.; Lee, J.; Lee, H. Sequestering carbon dioxide into complex structures of naturally occurring gas hydrates. Proc. Natl. Acad. Soc. USA. 2006, 103 (34), 12690-12694. 
(21) Lee, Y.; Seo, Y.; Ahn; T.; Lee, J.; Lee, J. Y.; Kim, S. J.; Seo, Y. CH4-Flue gas replacement occurring in $\mathrm{sH}$ hydrates and its significance for $\mathrm{CH}_{4}$ recovery and $\mathrm{CO}_{2}$ sequestration. Chem. Eng. J. 2017, 308, 50-58.

(22) Kvamme, B. Thermodynamic Limitations of the $\mathrm{CO}_{2} / \mathrm{N}_{2}$ Mixture Injected into $\mathrm{CH}_{4}$ Hydrate in the Ignik Sikumi Field Trial. J. Chem. Eng. Data 2016, 61 (3), 1280-1295.

(23) Lim, D.; Ro, H.; Seo, Y., Seo, Y.; Lee, J. Y.; Kim; S. J.; Lee, J.; Lee, H. Thermodynamic stability and guest distribution of $\mathrm{CH}_{4} / \mathrm{N}_{2} / \mathrm{CO}_{2}$ mixed hydrates for methane hydrate production using $\mathrm{N}_{2} / \mathrm{CO}_{2}$ injection. J. Chem. Thermodyn. 2017, 106, 16-21.

(24) Koh, D. Y.; Kang, H.; Kim, D. O.; Park, J.; Cha, M.; Lee, H. Recovery of methane from gas hydrates intercalated within natural sediments using $\mathrm{CO}_{2}$ and a $\mathrm{CO}_{2} / \mathrm{N}_{2}$ gas mixture. Chem Sus Chem 2012, 5 (8), 1443-1448.

(25) Qin, J.; Kuhs, W. F. Calibration of Raman quantification factors of guest molecules in gas hydrates and their application to gas exchange processes involving $\mathrm{N}_{2}$. J. Chem. Eng. Data 2015, 60 (2), 369-375.

(26) Liu, J.; Yan, Y.; Xu, J.; Li, S.; Chen, G.; Zhang, J. Replacement micro-mechanism of $\mathrm{CH}_{4}$ hydrate by $\mathrm{N}_{2} / \mathrm{CO}_{2}$ mixture revealed by ab initio studies. Comp. Mater. Sci. 2016, 123, 106-110.

(27) Koh, D. Y.; Ahn, Y. H.; Kang, H.; Park, S.; Lee, J. Y.; Kim, S. J.; Lee, J.; Lee, H. OneDimensional Productivity Assessment for On-Field Methane Hydrate Production Using $\mathrm{CO}_{2} / \mathrm{N}_{2}$ Mixture Gas. AIChE J 2015, 61 (3), 1004-1014.

(28) Lim, D.; Ro, H.; Seo, Joo, Y.; Lee, Yong.; Lee, J.; Kim, S. J.; Park, Y.; Lee, H. Electrical Resistivity Measurements of Methane Hydrate during $\mathrm{N}_{2} / \mathrm{CO}_{2}$ Gas Exchange. Energy Fuels 2017, $31(1), 708-713$. 
(29) Yang, J.; Okwananke, A.; Tohidi, B.; Chuvilin, E.; Maerle, K.; Istomin,V.; Bukhanov, B.; Cheremisin, A. Flue gas injection into gas hydrate reservoirs for methane recovery and carbon dioxide sequestration. Energy Convers. Manage. 2017, 136, 431-438.

(30) Youn, Y.; Cha, M.; Kwon, M.; Park, J.; Seo, Y.; Lee, H. One-dimensional approaches for methane hydrate production by $\mathrm{CO}_{2} / \mathrm{N}_{2}$ gas mixture in horizontal and vertical column reactor. Korean J. Chem. Eng. 2016, 33 (5), 1712-1719.

(31) Lee, Y.; Kim, Y.; Lee, J.; Lee, H.; Seo, Y. $\mathrm{CH}_{4}$ recovery and $\mathrm{CO}_{2}$ sequestration using flue gas in natural gas hydrates as revealed by a micro-differential scanning calorimeter. Applied Energy 2015, 150, 120-127.

(32) Cha, M.; Shin, K.; Lee, H.; Moudrakovski, I. L.; Ripmeester, J. A.; Seo, Y. Kinetics of Methane Hydrate Replacement with Carbon Dioxide and Nitrogen Gas Mixture Using in Situ NMR Spectroscopy. Environ. Sci. Technol. 2015, 49 (3), 1964-1971.

(33) Shin, K.; Park, Y.; Cha, M.; Park, K. P.; Huh, D. G.; Lee, J.; Kim, S. J.; Lee, H. Swapping Phenomena Occurring in Deep-Sea gas hydrates. Energy Fuels 2008, 22 (5), 3160-3163.

(34) Schoderbek, D.; Boswell, R. Iġnik Sikumi \#1, gas hydrate test well, successfully installed on the Alaska North Slope. Fire in the Ice 2011, 11 (1), 1-5.

(35) Boswell, R. Ignik Sikumi Gas Hydrate Field Trial Completed. Fire in the Ice 2012, 12 (1), 15.

(36) Boswell, R.; Schoderbek, D.; Collett T. S.; Ohtsuki, S.; White, M.; Anderson, B. J. The Ignnik Sikumi Field Experiment, Alaska North Slope: Design, Operations, and Implications for $\mathrm{CO}_{2}-\mathrm{CH}_{4}$ Exchange in Gas Hydrate Reservoirs. Energy Fuels 2017, 31 (1), 140-153. 
(37) $\mathrm{Mu}$, L.; Solms, N. V. Methane Production and Carbon Capture by Hydrate Swapping. Energy Fuels 2017, 31 (4), 3338-3347.

(38) Starling, K. E. Thermo data refined for LPG. Part 1: Equation of state and computer prediction. Hydrocarb. Process. 1971, 50 (3), 101-104.

(39) Circone, S.; Kirby, S. H.; Stern, L. A. Direct Measurement of Methane Hydrate Composition along the Hydrate Equilibrium Boundary. J. Phys. Chem. B 2005, 109 (19), 9468-9475.

(40) Moridis, G. J.; Collett, T. S.; Dallimore, S. R.; Satoh, T.; Hancock, S.; Weatherill, B. Numerical studies of gas production from several $\mathrm{CH}_{4}$ hydrate zones at the Mallik site, Mackenzie delta, Canada. J. Petrol. Sci. Eng. 2004, 43 (3-4), 219-238.

(41) Collett, T. S.; Boswell, R.; Lee, M. W.; Andersen, J. B.; Rose, K.; Lewis, K. A. Evaluation of long-term gas-hydrate-production testing locations on the Alaska North Slope. SPE Reserv. Eval. Eng. 2012, 15 (02), 243-264.

(42) $\mathrm{Mu}$, L.; Solms, N. V. Hydrate thermal dissociation behavior and dissociation enthalpies in methane-carbon dioxide swapping process. J. Chem. Thermodyn. 2018, 117, 33-42.

(43) Lee, H.; Seo, Y.; Seo, Y. T.; Moudrakovski, I. L.; Ripmeester, J. A. Recovering Methane from Solid Methane Hydrate with Carbon Dioxide. Angew. Chem. Int. Ed. 2003, 42 (41), 50485051.

(44) Ota, M.; Morohashi, K.; Abe, Y.; Watanabe, M.; Smith Jr, R. L.; Inomata, H. Replacement of $\mathrm{CH}_{4}$ in the hydrate by use of liquid $\mathrm{CO}_{2}$. Energy Convers. Manage. 2005, 46 (11-12), 1680-1691.

(45) Ota, M.; Abe, Y.; Watanabe, M.; Smith Jr, R. L.; Inomata, H. Methane recovery from methane hydrate using pressurized $\mathrm{CO}_{2}$. Fluid Phase Equilibr. 2005, 228-229, 553-559. 
(46) McGrail, B. P.; Schaef, H. T.; White, M. D.; Zhu, T.; Kulkarni, A. S.; Hunter, R. B.; Patil, S. L.; Owen, A. T.; Martin, P. F. Using Carbon Dioxide to Enhance Recovery of Methane from Gas Hydrate Reservoirs: Final Summary Report. Technical Report 2007.

(47) Zhou, X.; Fan, S.; Liang, D.; Du, J. Replacement of Methane from Quartz Sand-Bearing Hydrate with Carbon Dioxide-in-Water Emulsion. Energy Fuels 2008, 22 (3), 1759-1764.

(48) Bai, D.; Zhang, X.; Chen, G.; Wang, W. Replacement mechanism of methane hydrate with carbon dioxide from microsecond molecular dynamics simulations. Energy Environ. Sci. 2012, 5, 7033-7041.

(49) Jacobson, L. C.; Hujo, W.; Molinero, V. Thermodynamic Stability and Growth of Guest-Free Clathrate Hydrates: A Low-Density Crystal Phase of Water. J. Phys. Chem. B 2009, 113 (30), 10298-10307.

(50) Walsh, M. R.; Koh, C. A.; Sloan, E. D.; Sum, A. K.; Wu, D. T. Microsecond Simulations of Spontaneous Methane Hydrate Nucleation and Growth. Science 2009, 326 (5956), 1095-1098.

(51) Yuan, Q.; Sun, C. Y.; Liu, B.; Wang, X.; Ma, Z. W. Methane recovery from natural gas hydrate in porous sediment using pressurized liquid $\mathrm{CO}_{2}$. Energy Convers. Manage. 2013, 67 (2), 257-264.

(52) Zhao, J. F.; Zhu, Z. H.; Song, Y. C.; Liu, W. G.; Zhang, Y.; Wang, D. Y. Analyzing the process of gas production for natural gas hydrate using depressurization. Applied Energy 2015, 142, 125-134.

(53) Zhang, L. X.; Kuang, Y. M.; Zhang, X. T.; Song, Y. C.; Liu, Y.; Zhao, J. F. Analyzing the Process of Gas Production from Methane Hydrate via Nitrogen Injection. Ind. Eng. Chem. Res. 2017, $56(26), 7585-7592$. 
(54) Zhao, J. F.; Zhang, L. X.; Chen, X. Q.; Fu, Z.; Liu, Y.; Song, Y. C. Experimental Study of Conditions for Methane Hydrate Productivity by the $\mathrm{CO}_{2}$ Swap Method. Energy Fuels 2015, 29 (11), 6887-6895. 